Działo J., Pomoc publiczna a polityka konkurencji w Unii Europejskiej w okresie kryzysu gospodarczego, „Economics and Law”, Polszakiewicz B., Boehlke J. (ed.), Vol. 13, No. 1/2014, pp. 211-224. DOI: http://dx.doi.org/10.12775/EiP.2014.016.

\title{
POMOC PUBLICZNA A POLITYKA KONKURENCJI W UNII EUROPEJSKIEJ W OKRESIE KRYZYSU GOSPODARCZEGO
}

\section{STRESZCZENIE}

Globalny kryzys gospodarczy spowodował konieczność zaangażowania państwa w ratowanie przed bankructwem wielu podmiotów gospodarczych, początkowo w sektorze finansowym, a następnie, w późniejszej fazie kryzysu, także w realnej sferze gospodarki. W krajach Unii Europejskiej działania te przyjmują formę pomocy publicznej, która jest szczegółowo uregulowana, ponieważ oznacza korzyści dla jej beneficjentów, a więc narusza reguły konkurencji rynkowej. W związku z tym udzielanie pomocy publicznej jest kontrowersyjne, gdyż potencjalnie wpływa ono niekorzystnie na politykę konkurencji prowadzoną w UE. Celem artykułu jest analiza i ocena wpływu udzielanej pomocy publicznej na politykę konkurencji w krajach UE w dobie kryzysu gospodarczego.

Słowa kluczowe: sektor finansowy, realna sfera gospodarki, kryzysowa pomoc publiczna Klasyfikacja JEL: H41, H50, L52, R28

“ Joanna Działo, Uniwersytet Łódzki, Wydział Ekonomiczno-Socjologiczny, Katedra Funkcjonowania Gospodarki, ul. Rewolucji 1905 r. 41, 90-214 Łódź, tel.: +48 4263551 61, e-mail: jdzialo@uni.lodz.pl. 


\title{
STATE AID AND COMPETITION POLICY IN THE EUROPEAN UNION IN THE PERIOD OF ECONOMIC CRISIS
}

\author{
SUMMARY
}

The global economic crisis has caused the need for the state involvement in process of rescuing before the bankruptcy of many economic entities, initially in the financial sector, and then, at a later stage of the crisis, also in the real economy. In the European Union action takes the form of state aid, which is strongly regulated because it means benefits for its beneficiaries, and therefore violates the rules of market competition. Therefore, the provision of state aid is controversial because it potentially affects adversely competition policy pursued in the EU. The purpose of this article is to analyze and assess the impact of the state aid on competition policy in the EU in the times of economic crisis.

Keywords: financial sector, real economy, crisis state aid

JEL Classification: H41, H50, L52, R28

\section{WSTĘP}

Jednym z najważniejszych negatywnych skutków globalnego kryzysu gospodarczego jest długotrwała recesja, która dotknęła większość gospodarek na całym świecie. Głównym wyzwaniem (obok konsolidacji finansów publicznych) stojącym dziś przed państwami UE, w tym Polską, jest przywrócenie zrównoważonego wzrostu gospodarczego. Wśród ekonomistów powszechne są opnie, że zrównoważony wzrost gospodarczy nie jest możliwy do osiągnięcia bez skutecznej konkurencji na jednolitym rynku wewnętrznym. Konkurencja jest dla przedsiębiorstw bodźcem do innowacji i rozszerzania działalności, co skutkuje korzyściami dla konsumentów, przedsiębiorców i całej gospodarki europejskiej.

Zapewnienie odpowiednich warunków dla inicjowania i podtrzymywania zachowań konkurencyjnych możliwe jest przy wykorzystaniu sprawiedliwej polityki konkurencji, która wymaga stosowania odpowiednich instrumentów, tj. zasad pomocy państwa, przepisów antymonopolowych oraz przepisów dotyczących połączeń przedsiębiorstw.

Właściwie prowadzona polityka konkurencji odgrywa szczególnie istotną rolę $\mathrm{w}$ okresie kryzysu gospodarczego. Jednym $\mathrm{z}$ instrumentów tej polityki, dość szeroko wykorzystywanym zwłaszcza w początkowej fazie kryzysu, 
jest udzielanie przedsiębiorcom wsparcia ze środków publicznych. Taka forma wsparcia (pomoc publiczna) jest w Unii Europejskiej szczegółowo uregulowana, ponieważ oznacza przysporzenie korzyści jej beneficjentom, a więc narusza reguły konkurencji rynkowej. Obecnie istotną kwestią staje się odejście od wyjątkowych środków wsparcia przyjętych w okresie głębokiego kryzysu. Należy stopniowo powracać do typowych instrumentów pomocy państwa, przede wszystkim instrumentów horyzontalnych, które pomogą gospodarce europejskiej wyjść z kryzysu i umożliwią utrzymanie równych szans dla przedsiębiorstw w całej UE.

Celem artykułu jest analiza i ocena wpływu udzielanej pomocy publicznej na politykę konkurencji w krajach UE w dobie kryzysu gospodarczego.

\section{ZNACZENIE POMOCY PUBLICZNEJ DLA KONKURENCYJNOŚCI PRZEDSIĘBIORSTW W UNII EUROPEJSKIEJ}

Unia Europejska bardzo dużą wagę przykłada do kwestii konkurencyjności gospodarek, czego wyrazem jest m.in. tzw. Strategia Lizbońska przyjęta na posiedzeniu Rady Europejskiej w marcu 2000 roku w Lizbonie. Jako nadrzędny cel wskazuje ona „zbudowanie najbardziej konkurencyjnej i dynamicznej, opartej na wiedzy gospodarki na świecie, zdolnej do trwałego rozwoju, tworzącej większą liczbę lepszych miejsc pracy oraz charakteryzującą się większą spójnością społeczno-ekonomiczną"1.

Mimo tego, iż dziś wiadomo, że większość celów przyjętych w Lizbonie okazała się (jak dotychczas) nierealnych, to nadal oczywiste jest, iż jedną z ważniejszych determinant konkurencyjności podmiotów gospodarczych jest polityka gospodarcza realizowana $\mathrm{w}$ danym kraju. Istotnym instrumentem realizowania tej polityki jest natomiast pomoc publiczna ${ }^{2}$, której udzielanie wzbudza wiele kontrowersji. $Z$ jednej strony wolny rynek wymaga ochrony konkurencji i tym samym zakazu udzielania pomocy przedsiębiorstwom. $Z$ drugiej strony często istnieje potrzeba wspierania przez państwo pewnych dziedzin gospodarki i wspomagania przemian strukturalnych.

${ }^{1}$ European Parliament, Lisbon European Council: Presidency Conclusion, 23 and 24 March 2000, http://www.europarl.europa.eu/summits/lis1_en.html (23.08.2013).

2 Pomoc udzielana przez państwo członkowskie lub ze źródeł państwowych, w jakiejkolwiek formie, która narusza lub grozi naruszeniem konkurencji przez uprzywilejowanie niektórych przedsiębiorstw lub produkcji niektórych towarów, w zakresie, w jakim wpływa ona negatywnie na wymianę handlową pomiędzy państwami członkowskimi. Zob. Traktat o Funkcjonowaniu Unii Europejskiej, Dz. Urz. UE, C 83/47, 30.03.2010. 
Biorąc pod uwagę istotne znaczenie pomocy publicznej zarówno dla rozwoju przedsiębiorstw jak i dla ochrony konkurencji należy postawić pytanie, czy państwo powinno wspierać przedsiębiorstwa, czy raczej chronić konkurencję? Wydaje się jednak, iż udzielenie jednoznacznej odpowiedzi na to pytanie jest niemożliwe. W zależności od modelu gospodarki pomoc publiczna jest w mniejszym lub większym stopniu wykorzystywana. W praktyce w wielu krajach istnieje tendencja do zapewnienia gwarancji równego traktowania podmiotów gospodarczych, ale $\mathrm{z}$ zachowaniem możliwości wspierania przez państwo niektórych podmiotów, spełniających określone kryteria.

Konieczność udzielania pomocy przedsiębiorstwom wynika z szeregu przesłanek. Biorąc pod uwagę pobudzanie konkurencyjności gospodarki istotna jest zwłaszcza pomoc na badania i rozwój, która motywowana jest głównie koniecznością poprawy innowacyjności podmiotów gospodarczych. Pomoc publiczna może być także uwarunkowana szybkimi przemianami technologicznymi, które stanowią istotne zagrożenie dla pewnych gałęzi przemysłu. W tych przypadkach pomoc publiczna stanowi element wspomagający dostosowania i nie zawsze narusza reguły rynku. Innym czynnikiem skłaniającym do udzielania przez państwo pomocy przedsiębiorstwom jest ochrona środowiska. Ponadto dość powszechnym zjawiskiem jest pomoc dla instytucji kulturalnych, pomoc udzielana dla rozbudowy infrastruktury transportowej, czy pomoc dla rolnictwa. Ważną kwestią jest także pomoc dla sektora małych i średnich przedsiębiorstw, ze względu na istotną rolę tych przedsiębiorstw w tworzeniu nowych miejsc pracy.

Rola instrumentów pomocy publicznej we wspieraniu konkurencyjności przedsiębiorstw zależy od przeznaczenia pomocy oraz możliwości jej wykorzystania przez beneficjenta. W ocenie wpływu pomocy publicznej na konkurencyjność można wykorzystać trzy kryteria klasyfikacji jej instrumentów:

1. kryterium kierunku przepływów pieniężnych, umożliwiającego wyodrębnienie tych instrumentów, których zastosowanie powoduje transfer wartości majątkowych do beneficjenta (zwłaszcza dotacje) lub zmniejszenie obciążeń finansowych (ulgi podatkowe);

2. kryterium przejrzystości, które dokonuje klasyfikacji instrumentów na:

- czynne - stosowane ex ante, które wyprzedzając działania przedsiębiorcy mogą być łatwo kontrolowane. Zalicza się do nich: dotacje, dopłaty do oprocentowania kredytów, wniesienie kapitału do spółki, pożyczki preferencyjne, poręczenia i gwarancje kredytowe oraz udzielone „Z góry” ulgi podatkowe, jak również odroczoną „Z góry” lub rozłożoną w czasie spłatę rat podatku lub płatności na rzecz funduszy;

- bierne - stosowane ex post, korygujące skutki działań przedsiębiorcy, które już nie mogą być monitorowane. Instrumenty te uwalniają 
przedsiębiorcę od zobowiązań finansowych. Zalicza się do nich: zaniechanie ustalania i poboru podatków, umorzenie zadłużenia wobec budżetu i funduszy, konwersję zadłużenia na kapitał spółki, odroczenie lub rozłożenie na raty zaległości podatkowych lub płatności wobec funduszy;

3. kryterium efektywności, które prowadzi do bardzo niesymetrycznego ich podziału na dotacje oraz pozostałe narzędzia. Dotacje stosowane są we wspieraniu przedsięwzięć o podwyższonym stopniu ryzyka, takich jak: prace badawczo-rozwojowe, szkolenia, czy działalność małych i średnich przedsiębiorstw ${ }^{3}$.

\section{POMOC PUBLICZNA DLA SEKTORA FINANSOWEGO I REALNEJ SFERY GOSPODARKI}

\subsection{WSPARCIE DLA SEKTORA FINANSOWEGO}

Kryzys finansowy i gospodarczy, którego pierwsze symptomy gospodarka światowa zaczęła odczuwać w 2007 roku, wywołał konieczność zaangażowania przez rządy poszczególnych państw UE dużych nakładów finansowych, aby zwalczać jego negatywne skutki, zwłaszcza w sektorze bankowym. W rezultacie, poziom pomocy publicznej w UE w 2008 roku w porównaniu do 2007 roku zwiększył się niemal pięciokrotnie do 279,6 mld euro i odpowiadał 2,2\% PKB UE. Było to wyłącznie spowodowane pomocą udzielaną przez państwa członkowskie instytucjom finansowym. Dla porównania w 2007 roku wielkość pomocy publicznej wynosiła 66,5 mld euro (0,52\% PKB UE). Jeśli nie uwzględni się pomocy państwa związanej z kryzysem, to łączna wartość pomocy publicznej w 2008 roku wynosiła 67,4 mld euro, co stanowiło 0,54\% PKB UE. Najwyższy udział pomocy publicznej w PKB w 2008 roku przy uwzględnieniu środków podjętych w związku z kryzysem finansowym miały Irlandia (20,2\%), Luksemburg (7,83\%), Belgia (5,63\%), Łotwa (5,05\%) i Wielka Brytania (4\%). Najniższy natomiast udział pomocy w PKB wystąpił we Włoszech (0,35\%), w Grecji (0,42\%), Austrii (0,46\%), na Słowacji $(0,53 \%)$ i w Hiszpanii $(0,56 \%)^{4}$.

${ }^{3}$ K. Rutkiewicz, Gtówne kierunki udzielania pomocy publicznej w Polsce $i$ jej wptyw na konkurencje, PTE Toruń Working Papers, No 32/2008, s. 32.

${ }^{4}$ T. Korbutowicz, Pomoc publiczna w UE w warunkach kryzysu gospodarczego, [w:] J. Kundera (red.), Globalizacja, europejska integracja a kryzys gospodarczy, Prawnicza i Ekonomiczna Biblioteka Cyfrowa, Wrocław 2011, s. 67. 
Pogarszająca się sytuacja gospodarcza skłoniła władze UE do podjęcia konkretnych działań, sformułowanych przez Komisję Europejską w 2008 roku . Według przyjętych założeń, kraje UE mogą udzielać instytucjom finansowym gwarancji, dokapitalizować je lub dokonać kontrolowanej likwidacji niektórych instytucji finansowych. Banki mogą korzystać z gwarancji państwa w przypadku udzielanych kredytów oraz emitowania nowych instrumentów dłużnych. Okres i zakres gwarancji powinien być ograniczony do niezbędnego minimum, a program gwarancji ma być oparty na odpowiednim wynagrodzeniu, płaconym przez instytucję finansową będącą beneficjentem programu. Jednocześnie beneficjenci nie mogą prowadzić agresywnej ekspansji i mają ograniczoną swobodę w prowadzeniu polityki handlowej (np. zakaz reklamy powołującej się na udzielone gwarancje). Gwarancja jest traktowana jako nadzwyczajny, przejściowy instrument i powinny jej towarzyszyć restrukturyzacja lub likwidacja poszczególnych podmiotów-beneficjentów.

Programy dokapitalizowania należą do kluczowych środków, jakie mogą podjąć państwa członkowskie w celu utrzymania stabilności i właściwego funkcjonowania rynków finansowych. Dokapitalizowanie przyczynia się do przywrócenia stabilności finansowej banku oraz pomaga odbudować zaufanie niezbędne do ponownego ożywienia rynku pożyczek międzybankowych. Ponadto dodatkowy kapitał pozwala pokryć straty ponoszone $\mathrm{w}$ okresie recesji i zmniejsza ryzyko upadłości banków. Co więcej, dokapitalizowanie banków pośrednio może poprawić sytuację w realnej gospodarce, gdyż „zastrzyki” kapitału państwa mogą zapobiec zawężeniu oferty kredytowej dla podmiotów gospodarczych i tym samym ograniczyć zjawisko przenoszenia się trudności rynków finansowych na inne sektory. W przypadku dokapitalizowania wymagane jest, aby było ono oparte na obiektywnych i niedyskryminujących kryteriach kwalifikacji, ograniczone do niezbędnego minimum oraz wyposażone $\mathrm{w}$ mechanizm zabezpieczający przed potencjalnymi nadużyciami lub nadmiernym zakłóceniem konkurencji. Państwo powinno otrzymać prawo do aktywów o wartości równej sumie dokapitalizowania, np. akcje uprzywilejowane $\mathrm{z}$ prawem do odpowiedniego wynagrodzenia. Cena emisyjna nowych akcji musi być ustalona w oparciu o wycenę rynkową. Ponadto, podmiot-beneficjent zobowiązany jest do przygotowania programu restrukturyzacji.

Innym rodzajem pomocy państwa adresowanej dla sektora finansowego są interwencje dotyczące aktywów. Na skutek kryzysu finansowego w wielu bankach pojawił się problem aktywów o obniżonej jakości, w przypadku

\footnotetext{
5 Zastosowanie zasad pomocy państwa do środków podjętych w odniesieniu do instytucji finansowych w kontekście obecnego, globalnego kryzysu finansowego, Dz. Urz. UE, C 270, 25.10.2008 r.
} 
których wartość rynkowa stała się rażąco niska w porównaniu do ich wartości księgowej. Znaczy to, że aktywa takie z bardzo dużym prawdopodobieństwem przyniosą straty posiadającemu je podmiotowi (jak np. kredyty hipoteczne subprime w USA). Problem ten wymusił działania państwa związane z "oczyszczeniem” aktywów banków oraz poprawną wyceną ich rynkowej wartości. Komisja wskazuje na różne metody rozwiązania problemu, np. poprzez wykup tych aktywów przez państwo lub ich ubezpieczenie. Państwo powinno otrzymać od beneficjenta stosowne wynagrodzenie za wdrożone działania pomocowe ${ }^{6}$.

$\mathrm{KE}$ dopuszcza także stosowanie innych (niż gwarancje) instrumentów wspierających płynność banków (np. w formie pożyczek dla sektora bankowego). Możliwa jest także kontrolowana likwidacja instytucji finansowej, która może być konsekwencją nieudanej restrukturyzacji lub stanowić element ogólnego programu gwarancji. Likwidacja taka musi spełniać określone kryteria, tj. proces sprzedaży ma być prowadzony na warunkach rynkowych, a instytucja finansowa lub rząd powinni uzyskać jak najwyższą cenę za sprzedawane aktywa i zobowiązania.

W okresie od 1 października 2008 roku do 1 października 2012 roku KE podjęła około 350 decyzji dotyczących przyznania pomocy publicznej dla sektora finansowego w oparciu o artykuł 107 ust. 3 Traktatu o Funkcjonowaniu Unii Europejskiej (TFUE). Działania pomocowe prowadzone były prawie we wszystkich państwach członkowskich UE, za wyjątkiem Bułgarii, Czech, Estonii, Malty i Rumunii. Wartość przyznanej pomocy finansowej w wymienionym okresie wyniosła 5058, 9 mld euro (40,3\% PKB UE). Przeważająca wielkość pomocy przyznana była w 2008 roku w kwocie 3394 mld euro (27,7\% PKB UE), głównie na gwarancje depozytów i obligacji bankowych. W kolejnych latach pomoc publiczna dotyczyła przede wszystkim dokapitalizowania banków i interwencji dotyczących aktywów; jednak ostatnio znów w coraz szerszym stopniu wykorzystywane są gwarancje. Ponadto, w okresie od 1 stycznia do 1 października 2012 roku UE przyznała sektorowi finansowemu dodatkową pomoc w wysokości 429,5 mld euro ${ }^{7}$.

Jeśli chodzi o wykorzystanie przyznanej pomocy, to w okresie od 1 października 2007 roku do 31 grudnia 2011 roku całkowita kwota wykorzystanych środków finansowych wyniosła 1615,9 mld euro (12,8\% PKB UE). Największa część tej sumy przeznaczona została na gwarancje bankowe

${ }^{6}$ Komisja Europejska, Komunikat w sprawie aktywów o obniżonej jakości, Bruksela 2009, http://ec.europa.eu/competition/state_aid/legislation/specific_rules.html (29.08.2013).

7 European Commission, Commission Staff Working Document Accompanying the Document: State aid Scoreboard 2012 Update - Report on State aid granted by the EU Member States, Brussels 2012, http://ec.europa.eu/competition/publications/annual_report/2012/part1_en (03.09.2013). 
(1085 mld euro, 8,6\% PKB), następnie na dokapitalizowanie (322 mld euro; 2,6\% PKB), na uwolnienie banków od złych aktywów (119,9 mld euro; $0,9 \% \mathrm{PKB})$ i wreszcie na instrumenty wspierające płynność (89 mld euro; $0,7 \% \mathrm{PKB})$.

Poniższa tabela przedstawia kwoty pomocy publicznej przyznane podmiotom sektora finansowego w poszczególnych krajach UE w okresie kryzysu finansowego.

Tabela 1. Pomoc publiczna przyznana instytucjom finansowym według rodzaju instrumentu w okresie od 1 października 2008 roku do 1 października 2012 roku.

\begin{tabular}{|c|c|c|c|c|c|c|c|c|c|c|}
\hline \multirow{2}{*}{ KRAJ } & \multicolumn{2}{|c|}{ DOKAPITALIZOWANIE } & \multicolumn{2}{|c|}{ GWARANCJE } & \multicolumn{2}{|c|}{$\begin{array}{l}\text { INTERWENCJE } \\
\text { DOTYCZACE } \\
\text { AKTYWÓW }\end{array}$} & \multicolumn{2}{|c|}{$\begin{array}{c}\text { INNE } \\
\text { INSTRUMENT WSPIE- } \\
\text { RAJACEE PŁYNNOŚĆ }\end{array}$} & \multicolumn{2}{|c|}{$\begin{array}{l}\text { RAZEM W LATACH } \\
2008-2012\end{array}$} \\
\hline & $\begin{array}{l}\text { MLD } \\
\text { EURO }\end{array}$ & $\begin{array}{c}\% \text { PKB } \\
W \\
2011 R\end{array}$ & $\begin{array}{l}\text { MLD } \\
\text { EURO }\end{array}$ & $\begin{array}{c}\% \text { PKB } \\
\text { W } \\
2011 R\end{array}$ & $\begin{array}{l}\text { MLD } \\
\text { EURO }\end{array}$ & $\begin{array}{c}\% \text { PKB } \\
\text { W } \\
2011 R\end{array}$ & $\begin{array}{l}\text { MLD } \\
\text { EURO }\end{array}$ & $\begin{array}{c}\% \text { PKB } \\
\text { W } \\
2011 R\end{array}$ & $\begin{array}{l}\text { MLD } \\
\text { EURO }\end{array}$ & $\begin{array}{c}\% \text { PKB } \\
\text { W } \\
2011 R\end{array}$ \\
\hline Belgia & 220,4 & 55,5 & 3310,0 & 884,2 & 228,2 & 77,7 & 00,0 & 00,0 & 3358,6 & 997,4 \\
\hline Bułgaria & 00,0 & 00,0 & 00,0 & 00,0 & 00,0 & 00,0 & 00,0 & 00,0 & 00,0 & 00,0 \\
\hline Czechy & 00,0 & 00,0 & 00,0 & 00,0 & 00,0 & 00,0 & 00,0 & 00,0 & 00,0 & 00,0 \\
\hline Dania & 114,6 & 66,1 & 5587,9 & 2245,8 & 22,3 & 11,0 & 77,9 & 33,3 & 6612,6 & 2256,1 \\
\hline Niemcy & 1114,6 & 44,5 & 4455,9 & 117,7 & 666,1 & 22,6 & 99,5 & 00,4 & 646,1 & 225,1 \\
\hline Estonia & 00,0 & 00,0 & 00,0 & 00,0 & 00,0 & 00,0 & 00,0 & 00,0 & 00,0 & 00,0 \\
\hline Irlandia & 990,6 & 557,9 & 3386,0 & 2246,7 & 554,0 & 334,5 & 440,7 & 226,0 & 5571,3 & 3365,2 \\
\hline Grecja & 335,8 & 116,6 & 885,0 & 339,5 & 00,0 & 00,0 & 88,0 & 33,7 & 1128,8 & 559,9 \\
\hline Hiszpania & 2209,3 & 119,5 & 3320,2 & 229,8 & 113,9 & 11,3 & 331,9 & 33,0 & 5575,3 & 553,6 \\
\hline Francja & 2267,7 & 11,3 & 3339,8 & 117,0 & 44,70 & 00,2 & 00,0 & 00,0 & 3371,2 & 118,6 \\
\hline Włochy & 220,0 & 11,3 & 1110,0 & 77,0 & 00,0 & 00,0 & 00,0 & 00,0 & 1130,0 & 88,2 \\
\hline Cypr & 11,8 & 110,1 & 33,0 & 116,9 & 00,0 & 00,0 & 00.0 & 00,0 & 44,8 & 227,0 \\
\hline Łotwa & 00,8 & 44,1 & 55,2 & 25,9 & 00,5 & 22,7 & 22,7 & 113,5 & 90,3 & 66,2 \\
\hline Litwa & 00,6 & 11,9 & 00,3 & 00,9 & 00,6 & 11,9 & 00,0 & 00,0 & 11,5 & 44,7 \\
\hline Luksemburg & 22,5 & 55,8 & 66,2 & 114,4 & 00,0 & 00,0 & 00,3 & 00,7 & 89,0 & 220,9 \\
\hline Węgry & 11,1 & 11,1 & 55,4 & 55,3 & 00,0 & 00,0 & 33,9 & 33,9 & 110,3 & 110,3 \\
\hline Malta & 00,0 & 00,0 & 00,0 & 00,0 & 00,0 & 00,0 & 00,0 & 00,0 & 00,0 & 00,0 \\
\hline Holandia & 337,6 & 66,3 & 2200,0 & 333,2 & 222,8 & 33,8 & 252,9 & 88,8 & 3313,3 & 552,0 \\
\hline Austria & 115,9 & 55,3 & 777,8 & 225,9 & 00,5 & 00,2 & 00,0 & 00,0 & 994,2 & 331,3 \\
\hline Polska & 333,9 & 99,2 & 333,9 & 99,2 & 00,0 & 00,0 & 00,0 & 00,0 & 667,8 & 118,3 \\
\hline Portugalia & 226,3 & 115,4 & 440,7 & 223,8 & 44,0 & 22,3 & 66,1 & 33,5 & 777,0 & 445,0 \\
\hline Rumunia & 00,0 & 00,0 & 00,0 & 00,0 & 00,0 & 00,0 & 00,0 & 00,0 & 00,0 & 00,0 \\
\hline Stowenia & 00,6 & 11,8 & 112,0 & 333,7 & 00,0 & 00,0 & 00,0 & 00,0 & 112,6 & 335,4 \\
\hline Stowacja & 00,7 & 11,0 & 22,8 & 44,1 & 00,0 & 00,0 & 00,0 & 00,0 & 33,5 & 55,0 \\
\hline Finlandia & 44,0 & 22,1 & 550,0 & 226,4 & 00,0 & 00,0 & 00,0 & 00,0 & 554,0 & 228,5 \\
\hline Szwecja & 55,0 & 11,3 & 1156,0 & 440,3 & 00,0 & 00,0 & 00,5 & 00,1 & 1161,6 & 441,8 \\
\hline
\end{tabular}




\begin{tabular}{|c|c|c|c|c|c|c|c|c|c|c|}
\hline \multirow{2}{*}{ KRAJ } & \multicolumn{2}{|c|}{ DOKAPITALIZOWANIE } & \multicolumn{2}{|c|}{ GWARANCJE } & \multicolumn{2}{|c|}{$\begin{array}{l}\text { INTERWENCJE } \\
\text { DOTYCZACE } \\
\text { AKTYWÓW }\end{array}$} & \multicolumn{2}{|c|}{$\begin{array}{c}\text { INNE } \\
\text { INSTRUMENT WSPIE- } \\
\text { RAJACCE PŁYNNOŚĆ }\end{array}$} & \multicolumn{2}{|c|}{$\begin{array}{c}\text { RAZEM W LATACH } \\
\text { 2008-2012 }\end{array}$} \\
\hline & $\begin{array}{l}\text { MLD } \\
\text { EURO }\end{array}$ & $\begin{array}{c}\% \text { PKB } \\
W \\
2011 R\end{array}$ & $\begin{array}{l}\text { MLD } \\
\text { EURO }\end{array}$ & $\begin{array}{c}\% \text { PKB } \\
W \\
2011 R\end{array}$ & $\begin{array}{l}\text { MLD } \\
\text { EURO }\end{array}$ & $\begin{array}{c}\% \text { PKB } \\
\text { W } \\
2011 \mathrm{R}\end{array}$ & $\begin{array}{l}\text { MLD } \\
\text { EURO }\end{array}$ & $\begin{array}{c}\% \text { PKB } \\
W \\
2011 R\end{array}$ & $\begin{array}{l}\text { MLD } \\
\text { EURO }\end{array}$ & $\begin{array}{c}\% \text { PKB } \\
\text { W } \\
2011 R\end{array}$ \\
\hline $\begin{array}{l}\text { Wielka } \\
\text { Brytania }\end{array}$ & 1114,6 & 66,6 & 4458,8 & 226,3 & 2248,01 & 114,2 & 551,9 & 33,0 & 8873,3 & 550,0 \\
\hline UE 27 & 7777,3 & 66,2 & 33646,6 & 228,9 & 4445,8 & 33,5 & 2216,3 & 11,7 & 55086,0 & 440,3 \\
\hline
\end{tabular}

Źródło: opracowanie własne na podstawie: European Commission, State Aid Scoreboard. Report on State aid granted by the EU Member States, Brussels 2012, http://ec.europa.eu/competition/state_aid/studies_reports/expenditure (29.08.2013).

Należy podkreślić, że we wszystkich sprawach dotyczących pomocy państwa związanej z kryzysem KE zwracała uwagę na konieczność możliwie jak największego wyeliminowania zakłóceń konkurencji i utrzymania funkcjonowania jednolitego rynku. Przykładem sprawy, w której podkreślono konieczność ograniczenia zniekształceń konkurencji było zgłoszenie projektu pomocy rządu irlandzkiego tylko dla sześciu banków irlandzkich poprzez udzielenie gwarancji państwowych. Komisja uznała, że taki projekt niesie za sobą poważne ryzyko odpływu kapitału od niepożądanych konkurentów. W konsekwencji rząd irlandzki musiał wprowadzić zmiany do projektu tak, aby program gwarancji był dostępny dla wszystkich banków wraz ze spółkami podległymi i oddziałami znajdującymi się w Irlandii ${ }^{8}$.

\subsection{WSPARCIE DLA REALNEJ SFERY GOSPODARKI}

Wraz z początkiem 2009 roku kryzys finansowy w sektorze bankowym zaczął się rozszerzać i stopniowo obejmować pozostałe sektory gospodarki. Było to między innymi wynikiem obniżonej skłonności do ponoszenia ryzyka przez banki, co z kolei skutkowało utrudnieniami w dostępie do kredytu i przełożyło się na spadek popytu i produkcji w realnej gospodarce. Aby przeciwdziałać tym niekorzystnym zjawiskom, Komisja Europejska kontynuowała politykę pomocy państwa związanej z kryzysem finansowym i gospodarczym. Przejawem tego postępowania było wydanie dwóch komunikatów dotyczących zasad postępowania $\mathrm{z}$ aktywami o obniżonej wartości we wspólnotowym sektorze bankowym oraz reguł pomocy $\mathrm{z}$ tymczasowych

${ }^{8}$ European Commission, Commission Staff Working Document Accompanying the Report from the Commission on Competition Policy 2008, Brussels 2009, http://ec.europa.eu/competition/publications/annual_report/2008/part2_en (04.09.2013), s. 49. 
wspólnotowych ram prawnych ułatwiających dostęp do finansowania w dobie kryzysu finansowego i gospodarczego'.

Reguły te miały przeciwdziałać obniżeniu płynności banków, dostępności kredytu dla podmiotów gospodarczych i przyczynić się do ożywienia gospodarki. Aby ułatwić podmiotom gospodarczym dostęp do źródeł finansowania, przewidziano różne formy pomocy publicznej dla realnej sfery gospodarki. Jedną z nich są bezpośrednie granty dla przedsiębiorstw, w wysokości do 500 tys. euro. Ponadto, przewidziana jest pomoc w formie gwarancji pożyczki, co pozwala władzom przyznać pomoc w formie subsydiowanych pożyczek na inwestycje i pożyczek na kapitał obrotowy. Dopuszcza się także pomoc przedsiębiorstwom $\mathrm{w}$ formie zredukowanych stóp procentowych od kredytów, zwłaszcza w przypadku podmiotów inwestujących w wytwarzanie produktów ekologicznych. Proponuje się również programy pomocy dotyczące dostępu małych i średnich przedsiębiorstw do kapitału podwyższonego ryzyka (zwłaszcza we wczesnej fazie ich rozwoju) czy też ubezpieczenia kredytu eksportowego. Ponieważ pomoc publiczna w ramach tymczasowych ram prawnych przeznaczona była na realizację celów horyzontalnych, kraje UE mogą jej udzielać przedsiębiorstwom z każdego sektora gospodarki.

W latach 2009 i 2010 (łącznie) rozmiary wykorzystanej pomocy wynikającej z przyjęcia tymczasowych ram prawnych wyniosły 32,7 mld euro (0,26\% PKB UE). W roku 2011 państwa członkowskie wykorzystały pomoc o wartości około 4,8 mld euro (0,037\% PKB UE), a więc o ponad połowę mniej niż w roku 2010. Generalnie, państwa członkowskie wykorzystały około $45 \%$ pomocy przyznanej $\mathrm{w}$ ramach tymczasowych ram prawnych. Jednym z powodów relatywnie niskiego wykorzystania środków były ostre kryteria i wysoka dyscyplina ich przyznawania. $Z$ drugiej strony, powodem mogła być rosnące ograniczenia budżetowe w państwach członkowskich, będące wynikiem wysokich deficytów budżetowych i publicznego zadłużenia.

Tabela 2. Pomoc publiczna w UE w latach 2009-2011 udzielona w ramach tymczasowych ram prawnych

\begin{tabular}{|c|c|c|c|}
\hline KRAI & $\begin{array}{c}\text { POMOC PRZYZNANA } \\
\text { W LATACH 2009-2011 } \\
\text { W MLD EURO }\end{array}$ & $\begin{array}{c}\text { POMOC WYKORZYSTANA } \\
\text { W ROKU 2011 } \\
\text { W MLD EURO }\end{array}$ & $\begin{array}{c}\text { POMOC JAKO \% PKB } \\
\text { W 2011 ROKU }\end{array}$ \\
\hline EU-27 & 82,9 & 4,8 & 0,04 \\
\hline Belgia & 8,1 & 0,2 & 0,05 \\
\hline Bułgaria & 0,001 & 0 & 0 \\
\hline
\end{tabular}

9 Tymczasowe wspólnotowe ramy prawne w zakresie pomocy państwa utatwiajace dostęp do finansowania w dobie kryzysu finansowego i gospodarczego, Dz. Urz. UE C 83/1, 07.04.2009. 


\begin{tabular}{|c|c|c|c|}
\hline KRAJ & $\begin{array}{l}\text { POMOC PRZYZNANA } \\
\text { W LATACH 2009-2011 } \\
\text { W MLD EURO }\end{array}$ & $\begin{array}{c}\text { POMOC WYKORZYSTANA } \\
\text { W ROKU } 2011 \\
\text { W MLD EURO }\end{array}$ & $\begin{array}{c}\text { POMOC JAKO \% PKB } \\
\text { W } 2011 \text { ROKU }\end{array}$ \\
\hline Czechy & 1,1 & 0,1 & 0,06 \\
\hline Dania & 0,0 & 0 & 0 \\
\hline Niemcy & 29,6 & 0,7 & 0,03 \\
\hline Estonia & 0,2 & 0 & 0 \\
\hline Irlandia & 0,4 & 0,01 & 0,004 \\
\hline Grecja & 4,0 & 0,1 & 0,04 \\
\hline Hiszpania & 2,5 & 0,4 & 0,04 \\
\hline Francja & 0,6 & 1,6 & 0,08 \\
\hline Włochy & 0,4 & 0,7 & 0,04 \\
\hline Cypr & 0,0 & 0 & 0 \\
\hline Łotwa & 0,6 & 0 & 0 \\
\hline Litwa & 0,1 & 0,001 & 0,002 \\
\hline Luksemburg & 0,5 & 0 & 0 \\
\hline Węgry & 9,7 & 0,01 & 0,01 \\
\hline Malta & 0,04 & 0 & 0 \\
\hline Holandia & 0,0 & 0,02 & 0,003 \\
\hline Austria & 10,2 & 0,004 & 0,001 \\
\hline Polska & 0,2 & 0 & 0 \\
\hline Portugalia & 0,8 & 0,2 & 0,09 \\
\hline Rumunia & 0,4 & 0 & 0 \\
\hline Słowenia & 1,3 & 0,2 & 0,55 \\
\hline Słowacja & 0,4 & 0,005 & 0,01 \\
\hline Finlandia & 0,5 & 0,03 & 0,01 \\
\hline Szwecja & 1,3 & 0,7 & 0,17 \\
\hline Wielka Brytania & 10,1 & 0,0005 & 0,00003 \\
\hline
\end{tabular}

Źródło: opracowanie własne na podstawie: European Commission, State Aid Scoreboard. Report on State aid granted by the EU Member States, Brussels 2012, http://ec.europa.eu/competition/state_aid/studies reports/expenditure (29.08.2013).

\section{ZAKOŃCZENIE}

Podsumowując prowadzone $\mathrm{w}$ artykule rozważania należy stwierdzić, że pomoc publiczna jest dopuszczalna, a czasem niezbędna z punktu widzenia realizacji określonych celów społecznych i gospodarczych, o ile nie zakłóca 
konkurencji. Jednak w wielu przypadkach formy i sposoby udzielania pomocy publicznej naruszają reguły wolnorynkowej konkurencji i godzą w konstytucyjne gwarancje równości gospodarczej. Jest to szczególnie widoczne w okresie kryzysu gospodarczego. Wyraźne zwiększenie możliwości udzielania przez kraje UE pomocy publicznej związanej z kryzysem finansowym rodzi niebezpieczeństwo naruszenia zasad jednolitego rynku wewnętrznego i zakazu udzielania sprzecznej ze wspólnotowym prawem konkurencji pomocy publicznej. Pojawiają się opinie, że działania państw członkowskich związane z kryzysem stanowią wyzwanie dla procesu integracji europejskiej i poważne jego zagrożenie. Skala interwencji państw członkowskich w związku z kryzysem finansowym i pięciokrotny niemal wzrost kwoty pomocy w 2008 roku w porównaniu do roku 2007 stanowią poważne ograniczenie konkurencji i integralności jednolitego rynku.

Jednocześnie należy zwrócić uwagę na fakt, że rozmiary udzielonej pomocy zmniejszają możliwości Komisji odnośnie do sprawowania efektywnego nadzoru nad stosowanymi przez państwa członkowskie instrumentami interwencji gospodarczej. Podobnie nadmiernie rozbudowana interpretacja zasad udzielania pomocy przedstawiana w formie wytycznych, komunikatów, informacji czy ram prawnych stanowi swoiste potwierdzenie wyraźnego rozluźnienia podejścia KE do kwestii zakresu pomocy publicznej. Co więcej, w swoich sprawozdaniach dotyczących pomocy publicznej Komisja podkreśla konieczność zniesienia nadmiernych ograniczeń konkurencji, a nie ich wyeliminowania.

Trudno jest dziś jednoznacznie określić jakie skutki dla krajów UE będzie miała kryzysowa pomoc publiczna. Nie ulega wątpliwości, że pochłonęła ona znaczące części PKB państw podejmujących interwencję i zwiększyła istotnie ich deficyt budżetowy i dług publiczny. W konsekwencji tych działań należy spodziewać się wyraźnego zaostrzenia polityki fiskalnej, skutkującego między innymi istotnym zwiększeniem obciążeń fiskalnych w krajach UE. To z kolei może wpłynąć negatywnie na kondycję podmiotów gospodarczych i pośrednio na ich konkurencyjność. Nie można jednak nie doceniać faktu, że pomoc publiczna udzielana w okresie kryzysu finansowego uratowała przed bankructwem wiele instytucji finansowych i przedsiębiorstw realnej sfery gospodarki oraz uchroniła wiele krajów UE od dramatycznej, długotrwałej recesji i drastycznego wzrostu bezrobocia. Dlatego analizując wpływ pomocy publicznej na konkurencyjność gospodarek należy także ten aspekt wziąć pod uwagę. 


\section{BIBLIOGRAFIA}

European Commission, Commission Staff Working Document Accompanying the Document: State aid Scoreboard 2012 Update - Report on State aid granted by the EU Member States, Brussels 2012, http://ec.europa.eu/competition/publications/annual_report/2012/part1_en (03.09.2013).

European Commission, Commission Staff Working Document Accompanying the Report from the Commission on Competition Policy 2008, Brussels 2009, http://ec.europa. eu/competition/publications/annual_report/2008/part2_en (04.09.2013).

European Commission, State Aid Scoreboard. Report on State aid granted by the EU Member States, Brussels 2012, http://ec.europa.eu/competition/state_aid/studies_ reports/expenditure (29.08.2013).

European Parliament, Lisbon European Council: Presidency Conclusion, 23 and 24 March 2000, http://www.europarl.europa.eu/summits/lis1_en.html (23.08.2013).

Komisja Europejska, Komunikat w sprawie aktywów o obniżonej jakości, Bruksela 2009, http://ec.europa.eu/competition/state_aid/legislation/specific_rules.html (29.08.2013).

Korbutowicz T., Pomoc publiczna w UE w warunkach kryzysu gospodarczego, [w:] J. Kundera (red.), Globalizacja, europejska integracja a kryzys gospodarczy, Prawnicza i Ekonomiczna Biblioteka Cyfrowa, Wrocław 2011.

Rutkiewicz K., Gtówne kierunki udzielania pomocy publicznej w Polsce i jej wptyw na konkurencje, PTE Toruń Working Papers, No 32/2008.

Traktat o Funkcjonowaniu Unii Europejskiej, Dz. Urz. UE, C 83/47, 30.03.2010.

Tymczasowe wspólnotowe ramy prawne w zakresie pomocy państwa utatwiajace dostęp do finansowania w dobie kryzysu finansowego i gospodarczego, Dz. Urz. UE C 83/1, 07.04.2009.

Zastosowanie zasad pomocy państwa do środków podjetych w odniesieniu do instytucji finansowych w kontekście obecnego, globalnego kryzysu finansowego, Dz. Urz. UE, C 270, 25.10.2008. 
